\title{
STRATEGIC FINANCIAL ANALYSIS OF THE FLOUR-AND-CEREALS INDUSTRY'S ENTERPRISES CAPITAL
}

\author{
Olha KHUDYK ${ }^{1}$ \\ Yuriy Fedkovych Chernivtsi National University, Ukraine
}

\begin{abstract}
The article is devoted to the theoretical and methodological principles of strategic financial analysis of capital. The purpose of the investigation is to develop the methodology aspects of the capital structure optimization of the flour-and-cereals industry's enterprises. Methodology. The dialectical method of understanding the economic processes is the theoretical and methodological basis of the investigation. Such methods are used for achieving the purpose of the article: analysis and synthesis, induction and deduction, abstract and logical method, comparison, modelling, methods of economic statistics, fuzzy sets. Results. On the basis of the present state of the methodology of the strategic financial analysis of company's capital, it is theoretically grounded methodological approach to the capital structure optimization of the flour-and-cereals industry's enterprises. As the result of the research, it is established that the level of equity profitability and effectiveness of company's financial and economic activity are connected with the structure of funding sources. Therefore, to determine the target capital structure, it is proposed to take into account comprehensively such factors as the adjusted profitability of capital (assets) before interest and weighted average cost of capital. Since the company's equity is characterized by a certain value, to determine the criterion of optimal capital structure, it is necessary to take into consideration the amount of expenses to maintain the existing funding structure. So, there is the necessity to use the modified model to assess the effect of financial leverage, considering the average cost of capital. The utilization of this criterion requires establishing additional limits of the optimal capital structure formation: restrictions on the functioning capital adequacy, on the level of financial stability, on the inalienability of differential of financial leverage, on the level of financial risk. The obtained results have the practical value because they contribute to systems integration of the strategic financial analysis of capital and the financial management requirements and create conditions for its implementation in practice of domestic enterprises. Value/originality. The suggested model of capital optimization can be used to determine its structure according to the necessity in loan capital and its limit value, which may involve the company at an acceptable level of financial risk.
\end{abstract}

Key words: capital, financial leverage, financial strategy, strategic financial analysis, structure of capital.

JEL Classification: G31, G32, M40

\section{Introduction}

In terms of dynamic changes in the environment, the achievement of an enterprise's strategic goals and the efficiency of its activity primarily depends on peculiarities of capital formation, which main purpose is to ensure the necessity of the funding sources of various types of activities taking into account the dynamics of the available financial potential and to acquire the balanced structure of these sources on the bases of the established optimization criteria. The level of economic growth in the long term and competitive advantages increase of any business entity depends on the choice and substantiation of an effective strategy for managing capital. All this proves the importance of strategic financial analysis of capital as a methodological basis for study strategies.
Issues of the strategic financial analysis of capital are considered in the works of many national and foreign scientists, including L.Ye. Basovskiy, I.O. Blank, T.V. Holovko, V.V. Kovalev, T.M. Kovalchuk, I.V. Nikitushkina, Ye.M. Sych. However, it is difficult to adapt the existing models of the capital structure optimization to the realities of Ukrainian economic practice and they do not take into account the features of the flour-and-cereals industry's enterprises operation in the conditions of risk and uncertainty.

The purpose of the investigation is to develop the methodology aspects of the capital structure optimization of the flour-and-cereals industry's enterprises.

\footnotetext{
Corresponding author:

${ }^{1}$ Department of Accounting, Analysis and Audit, Yuriy Fedkovych Chernivtsi National University.

Email: o-hudyk@chnu.edu.ua
} 


\section{The theoretical and methodological basis of capital structure optimization}

Since the capital is a complex economic category, its investigation requires the introduction of a systematic approach, which provides that strategic financial analysis should be a continuing process at all stages of the capital circulation (the formation of the required amount of capital for the effective strategies implementation; the optimization of the capital structure in the process of its using; the identification and elimination of defects in the enterprises activity, and the substantiation of the areas of capital reinvestment to ensure the effective functioning of the business in the long-term perspective). As the result of the strategic financial analysis, a set of alternative managerial decisions concerning the financial sources definition, their structure optimization, the volume of additional amounts of debt substantiation should be prepared. It is necessary to develop such decisions in accordance with the optimal ratio among different groups of assets and sources of funding to ensure financial stability and liquidity in the strategic perspective.

There is no consensus in the scientific literature about the issue, which capital structure is optimal because the utilization of every financial source has certain advantages and disadvantages. Thus, the advantages of equity include: the high capacity to generate income from all activities; provision of financial independence and solvency in the long term, which reduces financial risk and the probability of bankruptcy; the level of counterparties and creditors confidence incense (especially important in the presence of long-term contracts). However, the application of the equity as a major source of financial resources is quite burdensome for the company because of its high cost, limited volumes of attraction for the various activities expansion, the lack of tax incentives. That is, using only equity, a company lowers financial risks but limits the rates of its strategic development, because does not provide the required amount of financial resources. In turn, the benefits of loan capital application include the possibility of raising the return on equity due to the effect of financial leverage, the application of the tax shield. However, in the case of implementation of an unfavourable scenario for the enterprise, a high share of loan capital causes the financial risk increase, the solvency and financial stability reduction. The attraction of loan capital is a rather complex procedure since depends not only on the available company's financial potential but also on creditors' decision about the capacity, volumes, and conditions of involvement, financial market conjuncture, the state of the banking system. Thus, according to the advantages and disadvantages of different sources of funding application, it is necessary to develop managerial decisions concerning the achievement of a compromise between the amount of their involvement, based on the ratio of capital cost and the financial risk level, which in these economic conditions is the most appropriate, i.e. the optimal capital structure.

L.Ye. Basovskiy thinks that optimal capital structure is the ratio of equity and loan capital, which leads to a maximum value of shares (Basovskiy, 2008). This definition is quite common; on its bases, it is difficult to generate practical recommendations for a particular non-stock company. According to A.A. Pereseda, the optimization of the capital structure - the selection of the most favourable ratio of internal and external sources at each stage of the company's life cycle (Pereseda, 2002). Actually, the structure of capital depends on the strategic objectives, which are different for each stage of the company's life cycle. Quite logical, in our opinion, is the approach of I.O. Blank, T.V. Holovko, T.M. Kovalchuk, Ye.M. Sych. According to it, the optimal capital structure is such a ratio of own and loan capital, which provides the most effective proportionality between the rate of return on equity and the index of financial stability, that is, maximizes the market value of the company (Blank, 2008; Holovko, Sahova, 2002; Kovalchuk, 2015; Sych, Pylypenko, Stasyshen, 2010).

Practice shows that until today there is no universal criterion for decision-making regarding an optimal ratio of equity and loan capital for different enterprises of one industry and even for the same company at different stages of its development. At the same time, there are a number of theoretical concepts, revealing approaches to creating the optimal capital structure, which can be roughly grouped into two groups - the static and dynamic (Table 1). The static theories substantiate the existence of an optimal capital structure that maximizes the company's market value. Within this group of theoretical concepts, it is proposed to make the managerial decisions concerning the choice of funding sources on the basis of the optimal capital structure (the aim of decision-making is to achieve this optimal structure). The dynamic theories are based on deviations from the target function and capital structure.

The discussed theories of the formation of the optimal capital structure are based on contradictory approaches: from the mutual independence of the capital structure and the market value of the company to their mutual dependence. In addition, it should be noted that they can be used completely only in presence of developed financial market and absence of a financial crisis. Despite the fact that the existing theories of capital structure are internally consistent and logical within certain limits, in the practical management of capital structure, it is necessary to take into consideration not only quantitative parameters but also a set of important qualitative factors and industrial characteristics influencing the rational structure of funding sources. In connection with this, the process of optimization involves the establishment of a target capital structure of the flour-and-cereals industry's enterprises. In our 
Table 1

The systematization of capital structure optimization theories

\begin{tabular}{|c|c|c|}
\hline № & The theory & The main aspects \\
\hline \multicolumn{3}{|r|}{ The static theories of capital structure } \\
\hline 1 & Modigliani-Miller theory & $\begin{array}{l}\text { The market value of the company is not dependent on financing strategies (i.e., capital structure), and } \\
\text { is determined only by the efficiency of investment. }\end{array}$ \\
\hline 2 & Agent models & $\begin{array}{l}\text { The presence of agency conflicts due to asymmetric information. } \\
\text { Agent conflicts reduce the value of the enterprise: the loan capital has a disciplining effect. } \\
\text { The inclusion of agency costs and expenses related to "difficulties". }\end{array}$ \\
\hline 3 & Miller's Model & The optimal capital structure is determined by the ratio tax rates. \\
\hline 4 & Static compromise theories & $\begin{array}{l}\text { The optimal capital structure is determined by the ratio of costs and benefits of loan capital. } \\
\text { Focusing on the deviation of actual capital structure from a target level of leverage and the } \\
\text { determinants of the process of adaptation. }\end{array}$ \\
\hline 5 & Theory of hierarchy & $\begin{array}{l}\text { Enterprises prefer internal financing sources compared with external. } \\
\text { The debt burden reflects the necessity of external financing. }\end{array}$ \\
\hline \multicolumn{3}{|r|}{ The dynamic theories of capital structure } \\
\hline 6 & Signal models & $\begin{array}{l}\text { The presence of asymmetric information among investors and managers. } \\
\text { Managers can change the capital structure to represent corresponding signals to investors. }\end{array}$ \\
\hline 7 & $\begin{array}{l}\text { Dynamic compromise } \\
\text { theories }\end{array}$ & $\begin{array}{l}\text { The presence of the enterprise's target capital structure. } \\
\text { The existence of the deviation between actual and target levels of leverage. } \\
\text { The presence of convergence between these indicators. }\end{array}$ \\
\hline
\end{tabular}

Source: generalized on the basis of (Piatak, Haltsov, 2013; Nykytushkyna, Makarova, 2013; Samoilikova, 2014)

opinion, the target capital structure is a ratio of own and loan financing sources, which entirely provides the growth in capital performance criteria at acceptable risk level and creates the opportunity to form the sufficient funds on satisfactory terms.

\section{Development of capital structure optimization model for the flour-and-cereals industry's enterprises}

In the practice of financial management, different methodological approaches to capital structure optimization are used and, accordingly, different performance criteria of formation and utilization of capital (Table 2) are set.

As the result of the research, it is established that the level of equity profitability and effectiveness of company's financial and economic activity are connected with the structure of funding sources. Therefore, to determine the target capital structure, it is proposed to take into account such factors: the adjusted profitability of capital (assets) before interest and weighted average cost of capital. Since company's equity is characterized by a certain value, to determine the criterion of optimal capital structure, it is necessary to take into consideration the amount of expenses to

Table 2

The methodological approaches to the capital structure optimization used in the practice of financial management

\begin{tabular}{|c|c|c|c|}
\hline Method & Criterion & Legend & $\begin{array}{l}\text { Formula } \\
\text { number }\end{array}$ \\
\hline Method of WACC & $\mathrm{WACC}=\sum_{\mathrm{i}=1}^{\mathrm{n}} \mathrm{Y}_{\mathrm{i}}^{*} \mathrm{~V}_{\mathrm{i}} \rightarrow \min$ & $\begin{array}{l}\text { WACC - weighted average cost of capital; } \\
Y_{i} \text { - the proportion of each element in the total capital; } \\
V_{i} \text { - the relative value of each element of capital. }\end{array}$ & (1) \\
\hline $\begin{array}{c}\text { Method of return on } \\
\text { equity }\end{array}$ & $R_{E}=\frac{N I}{E} \rightarrow \max$ & $\mathrm{NI}$ - net income; E - equity. & (2) \\
\hline $\begin{array}{l}\text { Method of financial } \\
\text { leverage }\end{array}$ & $L=\frac{L C}{E} *\left(R_{c}-r\right) *(1-t) \rightarrow \max$ & $\begin{array}{l}\mathrm{L} \text { - the effect of financial leverage; } \mathrm{LC} \text { - loan capital; } \\
\mathrm{R}_{\mathrm{c}} \text { - the level of capital (assets) profitability before } \\
\text { interest; } \mathrm{r} \text { - the level of interest; } \mathrm{t} \text { - the tax level. }\end{array}$ & (3) \\
\hline $\begin{array}{l}\text { Method of income } \\
\text { volatility }\end{array}$ & $\frac{E B I T-D B}{\sigma_{E B I T}} \rightarrow \max$ & $\begin{array}{l}\text { EBIT - the income before interest and taxes; } \\
\text { DB - debt burden; } \sigma_{\text {EBIT- }} \text { sample standard deviation of } \\
\text { the income before interest and taxes; }\end{array}$ & (4) \\
\hline Method “EBIT-EPS” & $E P S=\frac{(1-t)(E B I T-F E)-D I V_{p}}{S} \rightarrow \max$ & $\begin{array}{l}\text { EPS - the income per ordinary share; } \\
\text { FE - the financial expense; } \\
\text { DIV } V_{p} \text { - the dividends on preferred shares; } \\
S \text { - the average number of ordinary shares. }\end{array}$ & $(5)$ \\
\hline Method of financial risk & Risk $\rightarrow$ min & Risk - the level of financial risk & (6) \\
\hline
\end{tabular}

Source: generalized on the basis of (Grachev, 2010; Diadiuk, Kruhlova, Foschan, 2014; Zagainova, 2006; Sysoeva, 2007) 
maintain the existing funding structure. So, there is the necessity to use the modified model to assess the effect of financial leverage, considering the average cost of capital (Zagainova, 2006):

$$
L_{M}=\frac{L C}{E} *(R c(1-t)-W A C C) \rightarrow \max .
$$

The utilization of the criterion (7) requires establishing additional limits of the optimal capital structure formation:

- the restriction on the functioning capital adequacy;

- the restrictions on the level of financial stability;

- the restriction on the inalienability of differential of financial leverage;

- the restriction on the level of financial risk.

To determine the minimum required amount of functioning capital, the predictive value of profits before interest and taxes (EBIT), current (CA) and non-current assets (NCA), the previous forecast of long-term (LTL $\left.{ }^{p}\right)$ and short-term liabilities $\left(\mathrm{STL}^{\mathrm{p}}\right)$, financial expenses $\left(\mathrm{FE}^{\mathrm{p}}\right)$ are considered. The prediction of equity is adjusted according to predictive addition to equity. The additionally required amount of loan capital can be determined:

$$
\Delta L C \geq \frac{N C A+C A-\left(E_{0}+\left((1-t) *(1-D I V) *\left(E B I T-F E^{p}\right)\right)-L T L^{p}-S T L^{p}\right.}{1-(1-t) *(1-D I V) * r_{\text {new }}} .
$$

where DIV - projected dividends, $r_{\text {new }}$ - the interest rate on the additional amount of loan capital.

The corrected forecast of financial expenses is defined by formula (9) and the adjusted weighted average interest rate on loan capital (i) - by formula (10):

$$
\begin{aligned}
& F E=F E^{p}+\Delta L C * r_{\text {new }}, \\
& i=\frac{F E *(1-t)}{L T L^{p}+S T L^{p}+\Delta L C}=\frac{F E *(1-t)}{L C} .
\end{aligned}
$$

The restrictions on the level of financial stability implies that the index of capital structure $\left(\mathrm{I}_{\mathrm{CS}}\right)$ and the index of long-term financial independence $\left(\mathrm{I}_{\mathrm{LF}}\right)$ should be limited by normative values that reflect the level of acceptable loan capital funding and assets financing policy under considering industrial characteristics of the company :

$$
\begin{aligned}
& I_{C S}=\frac{E}{L C} \leq 1,5 . \\
& I_{L F I}=\frac{E+L T L-N C A}{E+L T L} \leq 0,2 .
\end{aligned}
$$

The restriction on the inalienability of differential of financial leverage is the main condition of the existing capital structure efficiency and of financial stability preservation while financial capacity increasing by attracting additional amount of debt: the adjusted weighted average interest rate on loan capital excess of the adjusted profitability of capital (assets) before interest $\left(\mathrm{R}_{\mathrm{CA}}\right)$ leads to equity profitability decrease. It can be formalized as follows:

$$
R_{c} *(1-t)-i=R_{C A}-i \geq 0 \text {. }
$$

To substantiate the possible amounts of loan capital involvement, it is necessary to access the potential optimistic, realistic, and pessimistic level of the adjusted profitability of capital (assets) before interest and to calculate the differential of financial leverage for each of these levels. Since in unstable environmental conditions the managerial decisions associated with the additional amount of loan capital are characterized by a high level of risk, their justification should be carried out based on the principle of prudence. According to this principle and to triples of fuzzy numbers transformation rules, the function of adjusted profitability of capital (assets) before interest is considered as a line.

In accordance with interval paradigm for the selected criteria of effectiveness, there is an opportunity to obtain a negative result determined as $p, 0 \leq p \leq 1$. The concept of "opportunity" is similar to the concept of "probability" but it is not based on the coincidence hypothesis and does not establish the probability density in the interval of uncertainty. Obviously, in the case $R_{C A}^{\text {pes }} \geq i$ the level of financial risk p will be 0 . Similarly, if $R_{C A}^{o p t}<i$ then $\mathrm{p}=1$. If $R_{C A}^{\text {pes }}<i \leq R_{C A}^{o p t}$ then the level of financial risk can be estimated by the formula:

$$
p=\left(i-R_{C A}^{p e s}\right) /\left(R_{C A}^{o p t}-R_{C A}^{p e s}\right),
$$

and the amount of additional loan capital will be deemed appropriate if:

$$
p \leq p_{d}
$$

where $p_{d}$ - acceptable level of financial risk.

\section{Approbation of the suggested model of capital structure optimization}

As a result of the calculations, the following capital

\begin{tabular}{|c|c|c|c|c|c|}
\hline Indicators & 2016 & 2017 & 2018 & 2019 & 2020 \\
\hline 1 & 2 & 3 & 4 & 5 & 6 \\
\hline Financial result from operating activities, thousand hryvnias & 66990 & 112530 & 179772 & 274890 & 404849 \\
\hline Investment costs, thousand hryvnias & 30295 & 35933 & 41230 & 46525 & 51823 \\
\hline Financial expenses, thousand hryvnias & 16000 & 16000 & 16000 & 16000 & 96000 \\
\hline The financial result of economic activity, thousand hryvnias & 20695 & 60597 & 122542 & 212365 & 257026 \\
\hline Net income, thousand hryvnias & 16969.9 & 49689.54 & 100484.4 & 174139.3 & 210761.3 \\
\hline Dividends, thousand hryvnias & 4242.475 & 12422.39 & 25121.11 & 43534.83 & 52690.33 \\
\hline
\end{tabular}
structure forecast of PrAT "Korsun-Shevchenkivske Khlibopryimalne Pidpryiemstvo" is obtained according to the optimality criterion at an acceptable level of financial risk of $15 \%$ (Table 3 ).

The optimization of the investigated company's capital structure was carried out in several stages: initially, it

Table 3

Modelling of the target capital structure of PrAT "Korsun-Shevchenkivske Khlibopryimalne Pidpryiemstvo" 


\begin{tabular}{|c|c|c|c|c|c|}
\hline \multicolumn{6}{|c|}{ Ending of Tabl } \\
\hline 1 & 2 & 3 & 4 & 5 & 6 \\
\hline Addition to equity, thousand hryvnias & 12727.43 & 37267.16 & 75363.33 & 130604.5 & 158071 \\
\hline Equity (initial), thousand hryvnias & 174118 & 186845.4 & 224112.6 & 299475.9 & 430080.4 \\
\hline Equity, thousand hryvnias & 186845.4 & 224112.6 & 299475.9 & 430080.4 & 588151.4 \\
\hline Long-term liabilities, thousand hryvnias & 80000 & 80000 & 80000 & 80000 & 0 \\
\hline Short-term liabilities, thousand hryvnias & 142855 & 201805 & 289527 & 414292 & 585435 \\
\hline Loan capital, thousand hryvnias & 222855 & 281805 & 369527 & 494292 & 585435 \\
\hline Target capital, thousand hryvnias & 409700 & 505918 & 669003 & 924372 & 1173586 \\
\hline Non-current assets, thousand hryvnias & 165064 & 200997 & 242227 & 288754 & 340577 \\
\hline Current assets, thousand hryvnias & 244636 & 304921 & 426776 & 635618 & 833009 \\
\hline The share of equity & 0.4561 & 0.4430 & 0.4476 & 0.4653 & 0.5012 \\
\hline The share of loan capital & 0.5439 & 0.5570 & 0.5524 & 0.5347 & 0.4988 \\
\hline The cost of equity & 0.0227 & 0.0554 & 0.0839 & 0.1012 & 0.0896 \\
\hline The cost of loan capital & 0.0589 & 0.0466 & 0.0355 & 0.0265 & 0.1345 \\
\hline WACC & 0.0424 & 0.0505 & 0.0572 & 0.0613 & 0.1120 \\
\hline The adjusted profitability of capital (assets) before interest & 0.0734 & 0.1241 & 0.1698 & 0.2026 & 0.2467 \\
\hline Differential of financial leverage & 0.0146 & 0.0776 & 0.1343 & 0.1760 & 0.1122 \\
\hline Index of capital structure & 1.1927 & 1.2574 & 1.2339 & 1.1493 & 0.9954 \\
\hline Index of long-term financial independence & 0.3814 & 0.3391 & 0.3617 & 0.4339 & 0.4209 \\
\hline Criterion $E_{\mu}$ & 0.0371 & 0.0926 & 0.1390 & 0.1624 & 0.1341 \\
\hline
\end{tabular}

* taking into account the repayment of principal

Source: calculated according to Website of Stock Market Infrastructure Development Agency of Ukraine

was determined the necessity in additional loan capital for each period, and then - the loan capital structure to maximize the key criteria considering based restrictions. The average level of modified effect of financial leverage is 0.1130 .

\section{Conclusions}

The theoreticalgeneralization and newproblemsolving of the strategic financial analysis of capital is performed in the article, allowing improving its theoretical and methodological principles. On the basis of the research, it is theoretically grounded methodological approach to the capital structure optimization of the flour-andcereals industry's enterprises. The suggested model of capital optimization can be used to determine its structure according to the necessity in loan capital and its limit value, which may involve the company at an acceptable level of financial risk.

\section{References:}

Basovskij, L.E. (2008). Finansovyj menedzhment [Financial management], Infra-M, Moscow, Russia, 239 p.

Blank, I.O. (2008). Finansovyj menedzhment [Financial management], Elha, Kyiv, Ukraine, 724 p.

Holovko, T.V. \& Sahova, S.V. (2002). Stratehichnyj analiz [Strategic analysis], KNEU, Kyiv, Ukraine, 198 p.

Grachev, A.V. (2010). Analiz i upravlenie finansovoj ustojchivost'ju predprijatija [Analysis and management of enterprise financial stability], Finpress, Moscow, Russia, 336 p.

Diadiuk, M.A., Kruhlova, E.A. \& Foschan V.V. (2014). Financial leverage as a tool for assessing the risk of formation of the financial structure of the capital of a trading enterprise, BUSINESSINFORM, Vol. 9, pp. 272-278.

Zagainova, Yu.V. (2006). Formation of the capital structure of a commercial bank, Abstract PhD thesis, Novosibirsk, Russia, 21 p.

Kovaljov, V.V. (1997). Finansovyj analiz: Upravlenie kapitalom. Vybor investicij. Analiz otchjotnosti [Financial Analysis: Capital Management. The choice of investments. Reporting analysis], Finansy i statistika, Moscow, Russia, $432 \mathrm{p}$.

Kovalchuk, T.M. (2015). Stratehichnyj analiz [Strategic analysis], Chernivtsi National University, Chernivtsi, Ukraine, $424 \mathrm{p}$.

Peresada, A.A. (2002). Upravlinnia investytsijnym protsesom [Management of the investment process], Libra, Kyiv, Ukraine, $472 \mathrm{p}$.

Piatak, T.V. \& Haltsov, A.Yu. (2013). Ways to optimize the capital structure, analysis of theoretical achievements, Bulletin of NTU "KhPI", Vol. 49(1022), pp. 118-127.

Sysoeva, E.F. (2007). Comparative analysis of approaches to the problem of optimizing the structure of capital, Finansy i kredit, Vol. 25, pp. 55-59.

Sych, Ye. M., Pylypenko, O. V. \& Stasyshen, M. S. (2010). Stratehichnyj analiz [Strategic analysis], Karavella, Kyiv, Ukraine, 304 p. 
Nykytushkyna, Y.V. \& Makarova, S.H. (2013). Struktura kapitala korporacii: teorija i praktika [Capital structure of the corporation: theory and practice], MGU, Moscow, Russia, $125 \mathrm{p}$.

Samoilikova, A. (2014). The Building of Optimal Financing Structure of Enterprises' Innovation and Investment Activity, European Journal of Economic Studies, Vol. 2(8): pp. 85-92.

Website of Agency of Development of Stock Market Infrastructure of Ukraine [Electronic resourse]. - Access mode: https:9/smida.gov.ua/

\section{Ольга ХУДИК}

\section{СТРАТЕГИЧЕСКИЙ ФИНАНСОВЫЙ АНАЛИЗ КАПИТАЛА ПРЕДПРИЯТИЙ МУКОМОЛЬНО- КРУПЯНОЙ ПРОМЫШЛЕННОСТИ}

Аннотация. В статье рассматриваются теоретические и методологические проблемы стратегического финансового анализа капитала предприятия. Целью исследования является развитие методических основ оптимизации структуры капитала предприятий мукомольно-крупяной промышленности. Методика. Методологической и теоретической основой исследования является диалектический метод познания экономических процессов. При проведении исследования для достижения поставленной цели использовались следующие методы: анализа и синтеза, индукции и дедукции, абстрактно-логический, сравнение, моделирование, методы экономической статистики, теории нечетких множеств. Результаты исследования. На основе изучения современного состояния развития методики стратегического финансового анализа капитала обоснован методический подход к оптимизации структуры капитала предприятий мукомольно-крупяной промышленности. В результате проведенного исследования установлено, что эффективность использования собственного капитала и финансово-хозяйственной деятельности в целом находятся в тесной причинно-следственной связи со структурой источников финансирования. Поэтому для определения целевой структуры капитала предлагается комплексно учитывать такие показатели, как прогнозный уровень скорректированной рентабельности капитала (активов) до выплаты процентов и средневзвешенная стоимость капитала. Поскольку собственный капитал предприятия характеризуется определенной стоимостью, для определения критерия оптимальности структуры капитала возникает необходимость учета совокупной суммы расходов предприятия на поддержание существующей структуры источников финансирования. Поэтому возникает необходимость использования модифицированной модели для оценки эффекта финансового левериджа с учетом средневзвешенной стоимости капитала. Использование этого критерия требует обоснования дополнительных ограничений формирования оптимальной структуры капитала, среди которых считаем целесообразным выделение ограничения по достаточности функционирующего капитала, по уровню финансовой устойчивости, на положительность дифференциала финансового левериджа, по уровню финансового риска. Полученные результаты имеют практическую ченность, поскольку будут способствовать системной интеграции стратегического финансового анализа с требованиями финансового менеджмента и создадут предпосылки для его внедрения в практику отечественных предприятий. Значение/оригинальность. Предложенная модель оптимизации капитала позволяет моделировать его структуру исходя из потребности в заемном капитале в каждый момент времени и его предельного объема, который может привлечь предприятие при приемлемом уровне финансового риска. 